\title{
$\alpha$-Fetoprotein maybe "dead-and-buried" as a marker of hepatocellular carcinoma in resource-rich countries, but it is still "alive-and-well" and needed in Sub-Saharan Africa
}

\section{L'alphafœtoprotéine peut être considérée comme " morte et enterrée " en tant que marqueur de carcinome hépatocellulaire dans les pays riches, mais elle reste « bien vivante » et indispensable en Afrique subsaharienne}

\author{
M.C. Kew \\ C) Springer-Verlag France 2013
}

$\alpha$-Fetoprotein $(\alpha-\mathrm{FP})$ is an $\alpha_{1}$ - globulin present in high concentration in foetal serum of mammals. It is the dominant plasma protein of the developing embryo, and is synthesized by the embryonal liver, the endodermal cells of the visceral yolk sac, and, in very small amounts, the embryonal intestine [1]. Approximately $80 \%$ of foetal hepatocytes synthesize and secrete the protein. The close conservation of $\alpha$-FP through phylogenesis suggests that it has functions essential to the foetus, although precisely what these functions are remains to be determined. But there does appear to be an inverse relation between serum $\alpha$-FP and albumin levels, suggesting that the protein might function as foetal albumin [2]. Other possible biological properties of $\alpha$-FP in the foetus include binding to oestrogens and bilirubin, immunosuppressive activity, and a growth-promoting potential [3]. After birth, production of $\alpha-\mathrm{FP}$ is almost completely repressed, and serum concentrations are correspondingly very low.

From the time of birth onwards $\alpha$-FP is synthesized almost exclusively by malignant hepatocytes. Its production is then permanent, irrespective of the serum level attained [2-4]. The molecular mechanism responsible for the reinduction of synthesis of the protein by malignant hepatocytes remains to be determined [4], although increased gene transcription plays a role [5]. Why not all hepatocellular carcinomas (HCCs) produce and secrete $\alpha$-FP has yet to be explained.

\footnotetext{
M.C. Kew $(\bowtie)$

Department of Medicine, University of Cape Town and Groote

Schuur Hospital, Cape Town

e-mail : michael.kew@uct.ac.za
}

Department of Medicine, University of the Witwatersrand, Johannesburg, South Africa
Raised serum levels of $\alpha$-FP have been used in the diagnosis of HCC since the 1960s. It has been most useful in recognizing the tumour in sub-Saharan Black African [6-8] and Far Eastern Chinese populations [9-11], both of which have very high incidences of HCC. Serum $\alpha$-FP levels are raised in as many as $87 \%$ of the sub-Saharan Black African patients with HCC, and in $75 \%$ of the patients the concentrations are raised above the diagnostic level [3,6-8]. The diagnostic level is defined as a level greater than that which may occasionally be present in patients with benign hepatic diseases (a level of greater than $500 \mathrm{ng} / \mathrm{ml}$ is used in some centres, $400 \mathrm{ng} / \mathrm{ml}$ in other centres, and $200 \mathrm{ng} / \mathrm{ml}$ in yet other centres). In addition, a progressively increasing serum $\alpha$-FP concentration, even if less than the diagnostic cut-off level, strongly suggests the presence of HCC.

In sub-Saharan Black African patients with HCC, the mean concentration of the raised serum $\alpha$-FP levels is 70,000 to $80,000 \mathrm{ng} / \mathrm{ml}$, but values as high as several (or even many) million are occasionally seen $[8,12]$. The raised serum concentrations are age-related-the younger the patient the higher the level attained $[4,8]$.

Accordingly, a raised serum $\alpha$-FP concentration is found in $96.4 \%$ and a diagnostically raised concentration in $89.3 \%$ of Black African patients with HCC under the age of 30 years, compared with $83.1 \%$ and $59.7 \%$, respectively, in those over the age of 50 years [13]. The mean value of the raised concentrations is $87,366 \mathrm{ng} / \mathrm{ml}$ in the younger patients and $43,827 \mathrm{ng} / \mathrm{ml}$ in the older patients [13]. The majority of Black Africans with HCC are young and live in rural areas. The mean age of rural-born and -living Black Africans with HCC in southern Africa is 34.7 years compared with 51.0 years in urban-born and -living Blacks and 50.9 years in rural-born Blacks who later migrate to the city [7,14]. Raised serum $\alpha$-FP concentrations are present in $89.7 \%$ of rural Black African patients with HCC, compared with $76.9 \%$ of 
urban patients (although the serum levels attained do not differ significantly between the two groups) [13]. The mean value of the raised concentrations is $87,366 \mathrm{ng} / \mathrm{ml}$ in the younger patients and $43,827 \mathrm{ng} / \mathrm{ml}$ in the older patients [12]. Serum $\alpha$-FP protein concentrations in age-matched Black men and women with HCC do not differ significantly [12].

No obvious correlation exists in Black African patients between serum $\alpha$-FP concentrations and any of the clinical or biochemical changes occurring in HCC, the degree of differentiation or size and stage of the tumour, or survival times after diagnosis [3,15]. Nor is there a correlation between serum $\alpha$-FP levels and the presence of chronic hepatitis $B$ virus (HBV) infection, the most frequent cause of HCC in sub-Saharan Black Africans: $\alpha$-FP levels are raised in $73 \%$ of the patients with and $80 \%$ of those without HBV surface antigenaemia [16]. This finding argues against the early postulate that $\alpha$-FP played a central role in the persistence of HBV infection [17], and hence in the pathogenesis of HCC in the Black African population.

In contrast, in patients with $\mathrm{HCC}$ in resource-rich regions, which have a low incidence of the tumour, serum $\alpha$-FP concentrations are raised appreciably less often and the levels attained are significantly lower than those in Black African and Chinese patients. For example, in Great Britain 28\% [18], in the United States 28 to 50\% [6], and in South African Caucasians 40\% [19] only of the patients have raised levels (but not diagnostically raised levels). In another study in Great Britain only $64 \%$ of the patients had serum $\alpha$-FP values above $10,000 \mathrm{ng} / \mathrm{ml}$ and only $9 \%$ values above $100,000 \mathrm{ng} / \mathrm{ml}$ [20]. In Greek patients with HCC the mean serum $\alpha$-FP concentration reached was $7,426 \mathrm{ng} / \mathrm{ml}$ [21] compared with $66,412 \mathrm{ng} / \mathrm{ml}$ in southern African Blacks $[8,15]$, and only $38 \%$ of the patients had a value greater than $12,100 \mathrm{ng} / \mathrm{ml}$ [21]. It follows that $\alpha$-FP is far less useful in the diagnosis of HCC and also in population screening for the tumour in these countries.

Possible explanations for the low positivity rate of $\alpha$-FP in resource-rich regions may be the generally older age of the patients with HCC in these regions (serum $\alpha$-FP levels are much lower in HCC occurring in populations in which the patients are older), and also the fact that the major cause of the tumour in these populations is chronic Hepatitis C Virus (HCV) infection rather than chronic HBV infection (serum $\alpha$-FP levels are lower in HCC in populations with HCVinduced HCC than in HBV-induced HCC [22]).

At the time that imaging of the liver in resource-rich regions, both as part of the diagnostic work-up for the detection of the tumour in individual patients or in mass population screening for early detection of small tumours, was largely unsuccessful and certainly far less successful than it is now, serum $\alpha$-FP levels, as limited in usefulness as they undoubtedly were, were nevertheless included in the diag- nostic work-up. But with the very sensitive imaging techniques now available in resource-rich regions for the detection of small HCCs - micro-bubble enhanced ultrasonography, triple-phase contrast enhanced spiral computed tomography, gadolinium-enhanced magnetic resonance T1-weighted imaging, and hepatic angiography - the rate of detection of small hepatic tumours has improved in these regions to such an extent that $\alpha$-FP with its low detection rates has become redundant. Hence, the appearance in journals emanating from these regions of articles with titles such as " $\alpha$ Fetoprotein: An obituary" [23] and " $\alpha$-Fetoprotein: The demise of a brilliant star" [24]. In addition, the American Association for the Study of Liver Diseases now recommends that $\alpha$-FP be excluded from the process of screening for early presymptomatic HCC [25].

But in resource-constrained sub-Saharan Africa, the availability of these modern very sensitive imaging techniques is limited to the best equipped medical centres in the large cities, and is non-existent in the rural areas, where the great majority of the Black African patients with HCC are seen. To the best of my knowledge no large-scale screening of Black Africans for HCC is currently taking place. Nevertheless, with the high incidence of the tumour in the Black African population, particularly in rural regions, it is fortunate that $\alpha-\mathrm{FP}$ is as useful a serum marker for the diagnosis of HCC as it is in this population, and that the test is accessible to rural patients. This justifies the continued availability and use of $\alpha-\mathrm{FP}$ as a marker for HCC in sub-Saharan Black Africans.

\section{References}

1. Gitlin D, Boesman M (1967) Sites of serum $\alpha$-fetoprotein synthesis in the human and in the rat liver. J Clin Invest 46:1010-6

2. Abelev GI (1971) $\alpha$-Fetoprotein in ontogenesis and its association with malignant tumour. Adv Cancer Res 14:295-358

3. Purves LR, Bersohn I, Geddes EW (1970) Serum $\alpha$-fetoprotein and primary cancer of the liver in man. Cancer (Philad.) 25:1261-70

4. Kew MC, Newberne PM (1982) Tumor markers in hepatocellular carcinoma. In: Okuda K, Mackay IR (eds) Hepatocellular carcinoma. UICC, Geneva, pp 122-35

5. DiBisceglie AM, Dusheiko GM, Paterson AC, et al (1986) Detection of $\alpha$-fetoprotein messenger RNA in human hepatocellular carcinoma and hepatoblastoma tissue. Br J Cancer 54:77985

6. Alpert ME (1976) Human $\alpha_{1}$-fetoprotein. In: Okuda K, Peters RL (eds) Hepatocellular carcinoma. Wiley, New York, pp 353-9

7. Kew MC, Geddes EW (1982) Hepatocellular carcinomas in rural southern African Blacks. Medicine (Balt.) 61:98-108

8. Kew MC (1989) Tumour markers in hepatocellular carcinoma. J Gastroenterol Hepatol 4:373-84

9. Lin TY, Chu SH, Chen MF, et al (1972) Serum $\alpha$-fetoprotein and primary cancer of the liver in Taiwan. Cancer 30:435-43 
10. Tsai JF, Chang WY, Jeng JE, et al (1994) Frequency of raised $\alpha$ fetoprotein level among Chinese patients with hepatocellular carcinoma related to hepatitis B and C. Cancer 69:1157-9

11. Johnson PJ (1999) Role of $\alpha$-fetoprotein in the diagnosis and management of hepatocellular carcinoma. J Gastroenterol Hepatol 14(Suppl):S32-S6

12. Kew MC, Macerollo P (1988) The effect of age on the etiological role of the hepatitis B virus in heptocellular carcinoma in Blacks. Gastroenterology 94:439-42

13. Kew MC, van Staden L, Bellingan A (1995) Serum $\alpha$-fetoprotein concentrations in urban and rural southern African Blacks with hepatocellular carcinoma. Trop Gastroenterol 16:11-5

14. Kew MC, Kassianides C, Hodkinson J, et al (1986) Hepatocellular carcinoma in urban-born Blacks: frequency and relation to hepatitis B virus infection. Brit Med J (Clin Res Ed) 293:133941

15. Kew MC (1975) $\alpha$-Fetoprotein. In: Read AE (ed) Modern Trends in Gastroenterology-5. Butterworths, London, pp 91-114

16. Kew MC, Geddes EW, MacNab GM, et al (1974) Hepatitis B antigen and cirrhosis in Bantu patients with primary liver cancer. Cancer 34:538-41
17. Ziegenfus JF (1973) Immunotherapy for Australia antigenassociated hepatoma. Lancet 1:1365-6

18. Kew MC, Dos Santos HA, Sherlock S (1971) Diagnosis of primary cancer of the liver. Br Med J 4(5784):408-11

19. Kew MC, Song E, Dusheiko GM (1984) Hepatocellular carcinoma in White South Africans: aetiological considerations. S Afr Med J 66:835-7

20. Koln J, Weaver PC (1947) Serum $\alpha$-fetoprotein in hepatocellular carcinoma. Lancet 2:334-6

21. Trichopoulos D, Sizaret P, Tabor E, et al (1980) $\alpha$-Fetoprotein levels of liver cancer patients and controls in a European population. Cancer 46:736-40

22. Kew MC (1996) Hepatitis B and C viruses and hepatocellular carcinoma. Clin Lab Med 16:395-406

23. Sherman M (2001) $\alpha$-Fetoprotein: an obituary. J Hepatol 34:6035

24. Forner A, Reig M, Bruix J (2009) $\alpha$-Fetoprotein for hepatocellular carcinoma diagnosis: the demise of a brilliant star. Gastroenterology 137:26-9

25. Bruix J, Sherman M (2005) Management of hepatocellular carcinoma. Hepatology 42:1208-36 